\title{
Pengembangan Bahan Ajar IPA Terpadu Bertemakan Lingkungan Berbasis Research Based Learning Untuk Meningkatkan Kemampuan Berpikir Kritis dan Kreatif Mahasiswa
}

\author{
Fanny Rahmatina Rahim ${ }^{1}$, Arief Muttaqiin ${ }^{2}$ and Aristo Hardinata ${ }^{3}$ \\ ${ }^{1}$ Department of Physics, Universitas Negeri Padang, Jl. Prof. Dr. Hamka Air \\ Tawar Padang 25131, Indonesia \\ ${ }^{2,3}$ Department of Science Education, Universitas Negeri Padang, Jl. Prof. Dr. \\ Hamka Air Tawar Padang 25131, Indonesia \\ ${ }^{1}$ fannyrahmatina@fmipa.unp.ac.id, ${ }^{2}$ muttaqiin.a@fmipa.unp.ac.id, \\ 33hardinata.a@fmipa.unp.ac.id
}

\begin{abstract}
Salah satu tema yang terdapat pada materi IPA Terpadu adalah lingkungan. Lingkungan merupakan sumber belajar yang konkret dan kontekstual bagi mahasiswa. Lingkungan menjadi tema yang sangat cocok untuk diterapkannya Research Based Learning. Berdasarkan hasil observasi dan wawancara dengan dosen pengampu mata kuliah IPA Terpadu diperoleh informasi bahwa dalam proses pembelajaran di kelas belum dilengkapi dengan buku pegangan untuk mahasiswa berupa bahan ajar. Dosen cenderung menggunakan buku paket yang digunakan oleh siswa SMP. Selain itu, buku yang digunakan belum mendorong mahasiswa untuk mengasah kemampuan berpikir kritis dan kreatif. Untuk itu, diperlukan upaya untuk menerapkan Research Based Learning ke dalam pembelajaran IPA Terpadu bertemakan lingkungan. Strategi yang dapat dilakukan oleh peneliti adalah dengan melakukan penelitian pengembangan suatu bahan ajar IPA Terpadu bertemakan lingkungan untuk meningkatkan kemampuan berpikir kritis dan kreatif mahasiswa. Tujuan penelitian pengembangan ini adalah untuk menghasilkan bahan ajar IPA Terpadu bertemakan lingkungan yang valid. Pengembangan bahan ajar IPA Terpadu bertemakan lingkungan menggunakan model pengembangan perangkat pembelajaran 4-D dengan alat pengumpul data lembar validasi.
\end{abstract}

